\title{
A TISZTESSÉGTELEN KERESKEDELMI GYAKORLATOK SZABÁLYOZÁSA ÉS JOGGYAKORLATA LENGYELORSZÁGBAN ${ }^{\mathrm{I}}$
}

\author{
Aneta Wiewiórowska-Domagalska
}

Debreceni Jogi Mühely, 2020. ÉVI (XVII. évfolyam) I-2. DOI I0.24I69/DJM/2020/I-2/8

\section{A szabályozás kialakulása és hatályos állapota}

A 2005/29/EK irányelvet ${ }^{2}$ (a továbbiakban: 2005/29/EK irányelv) a 2007. augusztus 23-án elfogadott, tisztességtelen kereskedelmi gyakorlat tilalmáról szóló lengyel törvény ${ }^{3}$ (a továbbiakban: UCPA) ültette át a lengyel jogrendbe. 2007. december 21-én lépett hatályba, kilenc nappal a 2005/29/EK irányelv 18. cikkében átültetésre előírt 2007. december 12-i határidőt követően.

A 2005/29/EK irányelv rendelkezéseinek átültetésével kapcsolatos legfontosabb kérdés az volt, hogy arra egy külön jogszabályban kerüljön-e sor, vagy a már meglévő tisztességtelen verseny tilalmáról szóló törvényben szabályozzák, annak módosítása útján. ${ }^{4} \mathrm{~A}$ külön jogszabály elfogadásának legfőbb indoka az volt, hogy függetlenül a két jogszabály hasonló szabályozási körétől és szankciórendszerétől, a címzettek köre eltér. A tisztességtelen verseny tilalmáról szóló törvény a vállalkozások érdekeinek védelmét szolgálja, míg az UCPA a fogyasztók érdekeit tartja szem előtt, ezért a vállalkozások csak közvetve részesülnek a törvény által biztosított jogosultságokból. Közös bennük, hogy mindkét törvény a piac tisztességes működését célozza meg, a közérdek védelmének egyfajta sajátos leképeződéseként. ${ }^{5}$

1 A tanulmány megírása és megjelentetése az Igazságügyi Minisztérium jogászképzés színvonalának emelését célzó programjai keretében valósult meg.

2 Az Európai Parlament és a Tanács 2005/29/EK irányelve (2005. május 11.) a belső piacon az üzleti vállalkozások fogyasztókkal szemben folytatott tisztességtelen kereskedelmi gyakorlatairól, valamint a 84/450/EGK tanácsi irányelv, a 97/7/EK, a 98/27/EK és a 2002/65/EK európai parlamenti és tanácsi irányelvek, valamint a 2006/2004/EK európai parlamenti és tanácsi rendelet módosításáról, HL L 149, 2005.6.11. 22-39.

3 Ustawa z dnia 23 sierpnia 2007 r. o przeciwdziałaniu nieuczciwym praktykom rynkowym, Hivatalos Lap 2017/2070. sz.

4 Tisztességtelen verseny tilalmáról szóló 1993. április 16-i törvény (Ustawa z dnia 16 kwietnia 1993 r. o zwalczaniu nieuczciwej konkurencji)

5 A Tisztességtelen verseny tilalmáról szóló 1993. április 16-i törvény indokolása 14. 
A 2005/29/EK irányelv külön jogszabályban történő átültetése a tisztességtelen verseny tilalmának és a tisztességtelen kereskedelmi gyakorlat tilalmának jogalkotói szétválasztásához vezetett. Egy ilyen megoldás mellékhatása az átfedés miatti nehézkes jogalkalmazás során nyilvánul meg. A problémák elkerülése érdekében az UCPA 18. \$-a akként módosította a tisztességtelen verseny tilalmáról szóló törvény 1 . \$-át, hogy kivette a fogyasztók védelmét a törvény szabályozási köréből. Ettől függetlenül, a tisztességtelen verseny tilalmáról szóló törvény egyes rendelkezései fogyasztóvédelmi érdekeket is szolgálhatnak. ${ }^{6}$ A két törvény kapcsolatából eredő vitás kérdésekkel a jogirodalom részletesen foglalkozik. ${ }^{7}$

A 2005/29/EK irányelv teljes harmonizációs elvével összefüggésében felmerült a kérdés, hogyan lehet az irányelv terminológiáját a lengyel jogrendszerhez igazítani, anélkül, hogy a nemzeti jogalkotás számára az uniós jog által biztosított szabadság határait megsértené. Ez nem ritkán a szó szerinti átvétel alkalmazásához vezetett, például az irányelv 2 . cikk d) pontjában szereplő meghatározással kapcsolatos értelmezési problémák elkerülése érdekében. ${ }^{8}$ A feketelistával kapcsolatban - a jellegéből adódóan - ugyancsak úgy döntött a jogalkotó, hogy a 2005/29/EK irányelv implementálásának egyetlen lehetséges módja a rendelkezések szó szerinti átültetése a lengyel jogszabályba. ${ }^{9}$

A 2005/29/EK irányelv módosította a fogyasztói érdekek védelme érdekében a jogsértés megszüntetésére irányuló eljárásokról szóló 98/27/EK irányelvet, azzal, hogy a 98/27/EK irányelv 1. cikk hatálya alá tartozó felsorolásban (azon irányelvek, amelyek megsértésére a 98/27/EK irányelvben meghatározott rendelkezések hatálya kiterjed) a 84/450/EGK irányelv helyére a 2005/29/EK irányelv került. Ennek eredményeként az UCPA módosította a gazdasági versenyről, valamint a fogyasztók védelméről szóló 2007 . február 16-án elfogadott lengyel törvény ${ }^{10}$ 24. \$-át, amely a fogyasztók kollektív érdekeit sértő kereskedelmi gyakorlatok tilalmát szabályozza.

6 A. Wiewiórowska-Domagalska, A. Kunkiel-Kryńska: Comments to Art. 1, Nb 67. In: K. Osajda (ed.): Tom VII. Komentarze Prawa Prywatnego. C.H.Beck, Warszawa, 2019.

7 J. Szwaja, A. Tischner: Implementacja dyrektywy 2005/29/WE o zwalczaniu nieuczciwych praktyk handlowych do prawa polskiego. Monitor Prawniczy, 2007/20. 1117; A. Tischner: Miejsce implementacji dyrektywy 2005/29/WE do prawa polskiego. In: E. Nowińska, D. Kasprzycki: Nieuczciwe praktyki rynkowe. Ocena regulacji, Kraków, 2012, 55.; M. Strzelecki: Nieuczciwe praktyki handlowe a ustawa o zwalczaniu nieuczciwej konkurencji. Ikar, 2016/3. 51.

8 A tisztességtelen verseny tilalmáról szóló törvény indokolása, 19.

9 A tisztességtelen verseny tilalmáról szóló törvény indokolása, 33.

10 Hivatalos Lap, 2018/798. sz., egységes szerkezetben (Dz.U.2018 r. 798 tj.) 
Az UCPA 24. $\$$ (2) bekezdése szerint a fogyasztók kollektív érdekeit sértő kereskedelmi gyakorlatnak minősül a vállalkozások által tanúsított minden olyan magatartás, amely a fogyasztók kollektív érdekeit sértő módon törvénybe vagy jóerkölcsbe ütközik. A (2) bekezdés tartalmaz egy nem kimerítő felsorolást is az ilyen gyakorlatokról, mint: a fogyasztók megbízható, valós és teljes körü tájékoztatására vonatkozó kötelezettség megsértése; tisztességtelen versennyel kapcsolatos magatartás; olyan pénzügyi szolgáltatások nyújtása a fogyasztók számára, amelyek - a szolgáltatást értékesítő fél rendelkezésére álló, az érintett fogyasztóval kapcsolatos információk alapján - nem felelnek meg a fogyasztók igényeinek; illetve, a szolgáltatások jellegét figyelembe véve, pénzügyi szolgáltatások rendeltetéstől eltérő módon történő nyújtása.

Míg az UCPA általánosságban olyan egyéni igényeket szabályoz, amelyek a tisztességtelen kereskedelmi gyakorlaton alapulnak, ${ }^{11}$ a gazdasági versenyről és a fogyasztók védelméről szóló törvény a jogérvényesítés (köz)igazgatási útjáról rendelkezik, ami egyébként a Verseny- és Fogyasztóvédelmi Hivatal (Urząd Ochrony Konkurencji i Konsumentów, továbbiakban: UOKiK) elnökének hatáskörébe tartozik. Az UOKiK elnöke e törvény alapján a fogyasztók kollektív érdekeit sértő esemény bekövetkezése esetén jogosult a közérdek védelmében fellépni.

Végezetül megemlíthetők a magatartási kódexek, s mint olyanok, a gazdaság különféle ágazataiban léteznek Lengyelországban. ${ }^{12}$ Sőt vannak olyan kezdeményezések, amelyek támogatják a vállalkozások csatlakozását is. ${ }^{13}$ Ennek ellenére Lengyelországban nincs olyan hatóság, amely felelős lenne a magatartási kódexek betartásának, továbbá különösen annak ellenőrzéséért, hogy a magatartási kódex egyúttal megvalósít-e tisztességtelen kereskedelmi gyakorlatokat.

11 A 15-17. $\$$ a tisztességtelen kereskedelmi gyakorlattal kapcsolatos büntetőjogi felelősséggel foglalkozik.

12 Például: https://radareklamy.pl/kodeks-etyki/ (letöltés dátuma: 2020.03.10.), https://zpf.plletyka/zasadydobrych-praktykl (letöltés dátuma: 2020.03.10.)

13 https://odpowiedzialnasprzedaz.pl/wp-content/uploads/2020/01/Regulamin_6-11.pdf (letöltés dátuma: 2020.03.12.) 


\section{Jogérvényesítési lehetőségek a tisztességtelen kereskedelmi gyakorlatokkal szemben}

$\mathrm{Az}$ tisztességtelen kereskedelmi gyakorlattal összefüggő bíróság előtti jogérvényesítés szabályait az UCPA szabályozza. A közigazgatási eljárásokat a hatóságok (UOKiK elnöke) folytatják le, ami egyúttal a 2005/29/EK irányelv kikényszerítésének egy párhuzamos, különálló útja.

Az UCPA 12. \$ (1) bekezdése, a mi egyúttal felsorolja azokat a tárgyköröket, amelyek esetén bírósághoz lehet fordulni tisztességtelen kereskedelmi gyakorlat miatt, a fogyasztókat egyértelmüen a törvény protektív rendelkezéseinek fó címzettjeiként jelöli meg. A fogyasztók mellett olyan más személyek vagy szervezetek is jogosultak bírósági eljárást kezdeményezni, ${ }^{14}$ mint az emberi jogi biztos, a pénzügyi ombudsman, országos vagy regionális szervezetek, amelyek célja a fogyasztói érdekek védelme, továbbá területi vagy települési önkormányzati fogyasztóvédelmi ombudsmanok. E személyek azonban - a fogyasztókhoz képest - csak korlátozott feltételekkel kezdeményezhetnek eljárást.

A tisztességtelen kereskedelmi gyakorlattal összefüggő fogyasztói igényérvényesítésnek nincs előre meghatározott sorrendje, azaz a fogyasztók közvetlenül fordulhatnak a bírósághoz.

Mindezek alapján, az UCPA és a tisztességtelen verseny tilalmáról szóló törvény erőteljesen egybefonódik. Ahogy a lengyel Legfelsőbb Bíróság (2014. május 8-i III SK 45/13. számú) ítéletében kifejtette, az Európai Bíróság joggyakorlatára, valamint a 2005/29/EK irányelv teljes harmonizációs elvére figyelemmel, a megtévesztő kereskedelmi gyakorlattal szembeni UOKiK elnöki beavatkozások kizárólagos jogalapját képezi az UCPA. Ezenfelül, a tisztességes versenyről, valamint a fogyasztók védelméről szóló törvény 25 . \szerint a törvényben meghatározott fogyasztóvédelmi intézkedések nem zárják ki más törvény által biztosított, így különösen az UCPA és a tisztességtelen versenyről szóló törvény szerinti jogok védelmét. Mindezek alapján lehetséges, hogy a tisztességtelen kereskedelmi gyakorlat az UCPA 12. $\$$ alapján egyéni igények alapjául szolgál, de a gazdasági versenyről és a fogyasztók védelméről szóló 24. \$ rendelkezése alapján kollektív igényérvényesítéshez is vezet (mint a fogyasztók kollektív érdekeit sértő kereskedelmi gyakorlat).

14 UPCA 12. \$(2) bek. 


\section{Fogyasztók bejelentése alapján induló eljárások a tisztességtelen kereskedelmi gyakorlatokkal kapcsolatban}

A tisztességtelen kereskedelmi gyakorlatok tilalmának hatósági úton történő kikényszerítéséről, a gazdasági versenyről, valamint a fogyasztók védelméről szóló törvény rendelkezik. Tisztességtelen kereskedelmi gyakorlatnak minősül az olyan kereskedelmi gyakorlat, amely a fogyasztók kollektív érdekeit sérti. ${ }^{15}$ Az UOKiK elnökének feladata, hogy a közérdek védelmében fellépjen, $s$ a sértő gyakorlatokat felszámolja.

A gazdasági versenyről és a fogyasztók védelméről szóló törvény 100 . \$ (1) bekezdése szerint bárki (azaz fogyasztók és vállalkozások egyaránt, csakúgy, mint fogyasztóvédelmi szervezetek, ombudsmanok, a Pénzügyi Ombudsman és a Pénzügyi Felügyeleti Hatóság) ${ }^{16}$ írásban bejelentést tehet az UOKiK elnökének, ha a fogyasztók kollektív érdekeit sértő kereskedelmi gyakorlat alkalmazása merül fel. Az ilyen bejelentésnek tartalmaznia kell mindenekelőtt: a vállalkozást, aki a feltételezett tisztességtelen kereskedelmi gyakorlat alkalmazója, a bejelentés alapjául szolgáló tények leírását, azt a jogszabályi rendelkezést, amelyet a vállalkozás vélhetőleg megsértett, a jogsértés valószínűsítését, és a bejelentő azonosító adatait. ${ }^{17}$

A bejelentés az UOKiK elnökét nem köti. Az elnök a bejelentés befogadásáról indokolatlan késedelem nélkül, de legkésőbb egy, az ügy különös bonyolultsága esetén két hónapon belül köteles értesíteni a bejelentőt, a befogadó vagy elutasító döntés indokainak előadásával egyidejüleg. ${ }^{18} \mathrm{~A}$ befogadással kapcsolatos döntéssel összefüggő tájékoztatás nem igényel határozati formát, ezért ellene fellebbezésnek sincs helye. ${ }^{19}$

15 M. Strzelecki: Praktyki naruszające zbiorowe interesy konsumentów w świetle zupetnej harmonizacji praktyk handlowowych wynikającej $z$ dyrektywy 2005/29/E o nieuczciwych praktykach handlowych. Krajowa Konferencja Konsumencka, 2016, 7.

16 T. Walczak: Postępowanie $w$ sprawach z zakresu ochrony zbiorowych interesów konsumentów jako szczególny rodzaj postępowania administracyjnego. (Rozprawa doktorska), Poznań, 2018, 180.

17 A tisztességes verseny és a fogyasztók védelméről szóló törvény 86 . $\$(2)$-(4) bek.

18 Lásd A. Jurkowska-Gomułka: Objaśnienia do art 100. \$. In: T. Skoczny (ed.): Ustawa o ochronie konkurencji i konsumentów. Komentarz. C.H.Beck, Warszawa, 2014, 1195.; D. Sylwestrzak: Postępowanie przed Prezesem Urzędu Ochrony Konkurencji i Konsumentów. Warszawa, LexisNexis, 2012, 168; K. Róziewicz-Ładoń: Postępowanie przed Prezesem Urzędu Ochrony Konkurencji i Konsumentów w sprawach praktyk ograniczajacych konkurencje. Warszawa 2011, 94; Walczak: i.m., 179.

19 A WSA (Vajdasági Közigazgatási Bíróság) határozata, Varsó, 2008. július 8. (VII SA/Wa 535/08, CBOSA) 
Az elnök nem köteles reagálni azokra a bejelentésekre, amelyek nem felelnek meg a bejelentéssel szemben támasztott, fentebb már kifejtett minimális követelményeknek. Ettől függetlenül, az elnök tájékoztatja a bejelentéstevőt az egyéni fogyasztói igény érvényesítésének lehetőségeiről. ${ }^{20}$

Az UOKiK elnöke által figyelembe vett szempontok könnyen hozzáférhetők. A hivatal weboldalán közzétett tájékoztatás ${ }^{21}$ hangsúlyozza, hogy a fogyasztók kollektív érdeke nem a különféle egyéni fogyasztói érdekek együttes érvényesítését jelenti, hanem azt, hogy a jogsértés következtében a fogyasztói jogok megsértése vagy veszélyeztetése tömeges, korlátlan jellegü - ahogy ezt a lengyel Fellebbviteli Bíróság is megerősítette. ${ }^{22} \mathrm{E}$ tájékoztatást alapul véve, az UOKiK elnöke csak abban az esetben indít eljárást, ha az egyes fogyasztói csoportok szempontjából különösen lényeges a jogsértés.

Az UOKiK elnöke az estek kiválasztása során az alábbi szempontok szempontokat veszi figyelembe:

a) a jogsértés kiterjedtsége (azaz potenciálisan milyen széles a fogyasztói kör, akiket a tisztességtelen kereskedelmi gyakorlat érint);

b) a jogsértés mértéke (azaz potenciálisan mennyire súlyos a fogyasztók gazdasági érdekeinek sérelme vagy fenyegetése);

c) ajogsértésmódja (vagyisavállalkozásjogellenestevékenységénekjellege);

d) az egyéni jogvédelem eszközeinek elérhetősége (vagyis van-e lehetőség a kereskedő jogellenes gyakorlatával szemben az érdekek védelmére az egyéni fogyasztók számára rendelkezésre álló igényérvényesítési eszközök útján);

e) az UOKiK elnöki beavatkozás következtében az összes fogyasztó által elérhető jelentős haszon mértéke, különösen a beavatkozáshoz szükséges kiadásokhoz viszonyítva.

Az elnöki eljárása lehet vizsgálati eljárás vagy fogyasztók kollektív érdekeinek megsértésével kapcsolatos eljárás. A vizsgálati eljárás esetlegesen jogsértőnek minősíthető egyes piaci folyamatok kivizsgálása érdekében kezdeményezhető, mely eseti jelleggel indul, és az eljárásnak nincs maghatározott alanya.

20 Walczak: i.m., 180.

21 https://www.uokik.gov.pllfaq_zagadnienia_ogolne.php\#faq1198. (letöltés dátuma: 2020.03.10.)

22 Fellebbviteli Bíróság VI Aca 306/08. számú, 2008. július 10-i ítélete. 


\section{Jogkövetkezmények alkalmazása a tisztességtelen kereskedelmi gyakorlatokkal szemben}

UOKiK elnöke 2016 óta - amikor is határozatában a fogyasztók kollektív érdekeit sértő kereskedelmi gyakorlatot állapított meg, és a gazdasági versenyről és a fogyasztók védelméről szóló törvény 26 . $\$(1)$ bekezdése alapján elrendelte annak betiltását - meghatározhatja a fogyasztók kollektív érdeksérelmével kapcsolatos elégtétel módját, a tilalom végrehajtásának biztosítása érdekében. Ennek keretében, az elnök egy vagy több nyilatkozat megtételére is kötelezheti a vállalkozást, a döntésben meghatározott formában és tartalommal. Az alkalmazott elégtétel a jogsértés súlyával és jellegével arányban kell, hogy álljon, és az elnök egyúttal elrendelheti a döntés közzétételét. ${ }^{23}$

Ezen felül, a fogyasztók kollektív érdekeit sértő kereskedelmi gyakorlattal kapcsolatos eljárásban, ha sor került a jogsértés megállapításra, és jogsértő vállalkozás kötelezettséget vállal arra, hogy a jogsértés megszüntetése, illetőleg a következmények elhárítása érdekében konkrét intézkedéseket kezdeményez, illetve tesz, az UOKiK elnöke határozatával a kötelezettségvállalásnak megfelelően kötelezheti a vállalkozást a jogsértés megszüntetésére, illetőleg a jogsértés következményeinek elhárítására. ${ }^{24} \mathrm{Az}$ elnök a kötelezettségvállalás teljesítésére jogosult határidőt kitűzni, továbbá kötelezheti a vállalkozást, hogy tájékoztassa a teljesítés elörehaladásával kapcsolatban. ${ }^{25}$

A gyakorlatban az UOKiK elnöke a vállalkozásokat a gazdasági versenyről és a fogyasztók védelméről szóló törvény 26 . $\$(2)$ bekezdése alapján meghatározott pénzösszeg fizetésére vagy meghatározott szolgáltatás teljesítésére kötelezheti a fogyasztók részére (tömeges kártérítés). A tömeges kártérítés felvet bizonyos ellentmondásokat a jogirodalomban, ugyanis egyrészről az az álláspont, hogy az elrendelésének jogalapja nem kielégítő, ${ }^{26}$ másrészről a tömeges kompenzáció gazdaságilag sem különbözik a bírságtól, amelyet az UOKiK elnöke ugyancsak kiszabhat a gazdasági versenyről és a fogyasztók védelméről szóló törvény 106. $\$(1)-(4)$ bekezdései alapján. Kohutek megjegyzi, hogy a tömeges kártérítés magánjogi természetű igény, azonban az UOKiK elnökének

23 A gazdasági versenyről és a fogyasztók védelméről szóló törvény 26. \$ (3)-(4) bek.

24 A gazdasági versenyről és a fogyasztók védelméről szóló törvény 28 . \$ (1) bek.

25 A gazdasági versenyről és a fogyasztók védelméről szóló törvény 26. \$ (2)-(3) bek.

26 K. Kohutek: Rekompensata publiczna - Kontrowersyjny środek stosowany przez prezesa UOKiK. 2018. 03. 08., elérhető: http://kohutek.pl/rekompensata-publiczna-kontrowersyjny-srodek-stosowany-prezesa-uokik/ (letöltés dátuma: 2020.03.10.) 
a tisztességtelen kereskedelmi gyakorlatokkal összefüggésben e tekintetben nincs hatásköre. ${ }^{27}$

Az UOKiK elnöke 2018-ban 26 vállalkozás esetében alkalmazott kötelezettségvállalást, annak érdekében, hogy kereskedelmi gyakorlatukat megváltoztassák. Ugyanebben az évben az 65 eljárást indított a fogyasztók kollektív érdekeit sértő gyakorlatokkal kapcsolatban, és 48 ilyen esetben hozott határozatot. ${ }^{28}$

A tisztességtelen kereskedelmi gyakorlatok következményeinek önkéntes elhárításának kérdése felmerül az UOKiK elnöke előtt folyó eljárások más szakaszaiban is. A bírság összegének a 11. \$ (3) és (4) bekezdés szerinti megállapítása során, az UOKiK elnöke enyhítő körülményeket mérlegelhet, amelyek magukban foglalhatják például a jogsértés következményeinek önkéntes elhárítását, tanúsított gyakorlat beszüntetését eljárás megindítása előtt vagy közvetlenül az eljárás megindítását követően, a vállalkozás saját elhatározásból tett intézkedéseit a jogsértés megállítására vagy annak következményeinek megszüntetése érdekében. Az enyhítő körülmények tehát magukban foglalhatják a tisztességtelen kereskedelmi gyakorlat következtében károsult személyek kárainak megtérítését, illetve enyhítését is. ${ }^{29}$

\section{A fogyasztók kártérítési lehetősége a tisztességtelen kereskedelmi gyakorlatokkal szembeni eljárás során}

Az UCPA 12. $\$$ (1) bekezdése tartalmaz egy felsorolást a fogyasztók által kérhető jogkövetkezményekről. E szakasz alapján, tisztességtelen kereskedelmi gyakorlat alkalmazása esetén a fogyasztó, akinek jogát vagy jogos érdekét a gyakorlat sértette vagy veszélyeztette, az alábbi jogkövetkezmények alkalmazását követelheti:

a) a jogsértés megszüntetését, illetőleg abbahagyását;

b) a jogsértés következményeinek a megszüntetését, továbbá nyilatkozat megtételét (egy vagy több alkalommal), megfelelő tartalommal és megfelelö formában.

27 K. Kohutek: $i . m$.

28 https://www.uokik.gov.pl/aktualnosci.php?news_id=16026 (letöltés dátuma: 2020.03.10.)

29 M. Sieradzka (ed.): Ustawa o przeciwdziataniu nieuczciwym praktykom rynkowym. Komentarz. Wolters Kluwer, Warszawa, 2008, 1054. 


\section{TISZTESSÉGTELEN KERESKEDELMI GYAKORLATOK - LENGYELORSZÁG}

c) kártérítést - az általános szabályoknak megfelelően - a jogsértéssel összefüggésben keletkezett valamennyi kárért, különösen követelheti a szerződés megszűntetését, a szolgáltatások kölcsönös visszatérítésének kötelezettségével együtt,

d) a termék megszerzésével kapcsolatos költségek megtérítését,

e) meghatározott összeg közérdekű célokra fordítását, amely a lengyel kultúra támogatására, a nemzeti örökség vagy a fogyasztók védelmére irányul.

A 12. $\$$ alapján a fogyasztó nemcsak akkor jogosult az igényérvényesítésre, ha a jogai sérelmet szenvedtek, hanem akkor is, ha a kereskedelmi gyakorlat a fogyasztók érdekeit veszélyezteti. A gyakorlatban a veszélyeztetést nyilvánvalóan sokkal nehezebb bizonyítani, mint a már megvalósult jogsértést, egyúttal magas fokú érzékenységet kíván meg a bíróságoktól a gyakorlatok lehetséges hosszú távú hatásainak értékelése során. ${ }^{30}$

A fogyasztók érdeke a 12. $\$$ alapján arra a gazdasági érdekre korlátozódik, amelyet a 2005/29 irányelv védendő célként határoz meg (ehhez képest a lengyel polgári perrendtartásról szóló törvény 189 . \szerinti jogi érdek szélesebb körü). Az UCPA-ban szereplő jogkövetkezmények katalógusa a tisztességtelen verseny elleni küzdelemről szóló törvényben meghatározott jogkövetkezmények listáján alapul $^{31}$ (bizonyos eltérésekkel). ${ }^{32}$ A követelések vagyoni jellegét az ítélkezési gyakorlat is elfogadta. ${ }^{33}$

A jogsértés megszüntetése/abbahagyása iránti kérelem esetén a fogyasztó kérheti a vállalkozást, hogy hagyjon fel egy bizonyos magatartással, vagy ha a gyakorlat mulasztásból áll, akkor bizonyos magatartást tanúsítson. A Varsói Fellebbviteli Bíróság 2017. szeptember 8-i ítéletében ${ }^{34}$ kimondta, hogy az ilyen igényt benyújtó fogyasztónak nagyon pontosan meg kell határoznia, mire terjed ki a követelése. Csak ez teszi ugyanis lehetővé a bíróság számára, hogy megtiltsa egy adott kereskedő olyan magatartását, amely tisztességtelen kereskedelmi gyakorlatnak minősül és sérti a fogyasztó érdekeit.

A gyakorlat következményeinek elhárítása értelemszerűen az okozott következmények helyreállításából áll. Ez azonban nem minden esetben lehetséges. Például, ha a jogsértés a televízióban közvetített reklámban valósult meg, akkor

30 Wiewiórowska-Domagalska, Kunkiel-Kryńska: i.m., Art. 12 Nb 17

31 A tisztességtelen verseny tilalmáról szóló törvény indokolása, 37.

32 Lásd Wiewiórowska-Domagalska, Kunkiel-Kryńska: i.m., Art. 12 Nb 21.

33 Lásd például a lengyel Legfelsőbb Bíróság 2016. június 2-i ítéletét (I CSK 119/16)

34 I Aca 985/16. 
a következmények helyreállítása olyan információ közzétételét jelentheti, amelyben helyesbítik a reklámban szereplő téves információkat. Nincs azonban garancia arra, hogy ez eljut minden, a jogsértő hirdetés által korábban érintett valamennyi személyhez.

Egy meghatározott tartalmú és formájú nyilatkozat egy vagy több alkalommal történő közzétételét az a bíróság rendeli el, egyes meghatározott médiumokban. Azt, hogy hol tehető közzé nyilatkozat, a törvény nem határozza meg pontosan, de a jogelméletben elfogadott, hogy ez az újságokat, rádiót, televíziót vagy az internetet is magában foglalja (beleértve a vállalkozás közösségi oldalakon közzétett tartalmait). ${ }^{35}$ A nyilatkozat megfogalmazása több célt is szolgál: oktatási célokat a fogyasztók érdekében, megelőzési célokat más vállalkozásokat tekintve, de represszív jellegű célokat is, az azzal járó költségek, valamint a kereskedő jó hírnevének sérelme miatt. ${ }^{36}$ Egy, a nyilatkozattételt elrendelő ítéletben ${ }^{37}$ például a bíróság ítéletének jogerőre emelkedésétől számított három hónapon belül a következő nyilatkozat közzétételét rendelte el: „A [név] társaság, mint mobiltelefon-hálózat üzemeltetö, ezúton elnézést kér $G$. L-töl minden olyan kellemetlenségért, amelyet egy telefon nem megfelelö müködésével összefüggó panaszeljárás nem megfelelo" kezelése során okozott". A bíróság a végzésben meghatározta azt az újságot, amelyben a közleményt közzé kellett tenni, továbbá azt az oldalszámot, ahol el kell helyezni a nyilatkozatot, továbbá a betű méretét és típusát, valamint azt, hogy a szövegben másfélszeres sorközt kell alkalmazni.

A 12 . $\$$ az okozott károk megtérítésének egyik általános szabályok szerinti módja, ami kiterjed különösen a szerződés megszüntetése következtében keletkezett károkra, a szolgáltatások kölcsönös visszatérítésének kötelezettségével együtt. Ezt az értelmezést a jogirodalom erősen kifogásolja, mivel a szerződés megszüntetése nem tartozik a kártérítések típusai közé. ${ }^{38}$ A helytálló csoportosítás két különálló igény biztosítása lenne. ${ }^{39} \mathrm{Az}$ a tény, hogy az UCPA a károk általános szabályok szerinti megtérítésére utal, azt jelenti, hogy az igény a meglévő általános szabályok szerinti kártérítési rendszer alá tartozik. Az a tény, hogy a szabály helytelenül lett megfogalmazva, megnehezíti annak alkalmazását is a gyakorlatban.

35 Sieradzka: i.m., Art. 18, Nb 13

36 Wiewiórowska-Domagalska: i.m., Art. $12 \mathrm{Nb}$ 41-44.

37 Katowicei Fellebbviteli Bíróság (V ACa 562/15)

38 M. Grochowski: Wadliwość umów konsumenckich (w świetle przepisów o nieuczciwych praktykach rynkowych. Państwo i Prawo, 2009/7. 60.

39 Grochowski: i.m., 60. 
Az általános szabályokra való hivatkozást a lengyel polgári törvénykönyv (Lptk.) 361-363. és 415. \$-ára történő hivatkozásként kell értelmezni. Ez azt jelenti, hogy a felelősség megállapításához be kell tartani a kárfelelősség előfeltételeit. ${ }^{40} \mathrm{~A} 415$. $\$$ akkor teszi lehetővé kártérítési felelősség megállapítását, ha a felek között nincs szerződéses jogviszony, vagy van, de a károsodás nem a szerződésből ered. Ez a szemlélet megegyezik a szerződéses kapcsolatokban és azokon kívül egyaránt előforduló tisztességtelen kereskedelmi gyakorlatokkal kapcsolatos helyzetekkel. Ha a tisztességtelen kereskedelmi gyakorlatot a szerződés nem vagy nem megfelelö teljesítéseként értékelhető, a fogyasztó helyreállíttathatja szerződést a megfelelő igényérvényesitési lehetőségekkel, ami magába foglalja a Lptk. 471. § szerinti kártérítés iránti igényt is.

$\mathrm{Az}$ a körülmény, hogy a kártéritési igény a kártéritési felelösség általános szabályain alapszik, együtt jár annak az elvi tételnek is az elfogadásával, hogy a vállalkozás felelőssége felróhatóságon alapul. ${ }^{41} \mathrm{~A}$ felróhatóság bizonyításának szükségessége azonban a fogyasztó számára adott esetben rendkívül nehéz lehet, és a gyakorlatban kizárhatja a hatékony kártéritési igényérvényesítést. Ez a körülmény a 2005/29/EK irányelv megfelelö átültetését illetően is aggodalomra ad okot (az irányelv szerint a fogyasztó rendelkezésére álló jogorvoslati lehetőségeknek kellően hatékonyaknak kell lenniük). ${ }^{42} \mathrm{~A}$ jogirodalom kimunkált olyan eszközöket, amelyek hatékonyabbá tehetnék a jogérvényesítést (ilyen például az anonim felróhatóság doktrínája). ${ }^{43} \mathrm{~A}$ kártérítési követelés egyébként kiterjedhet az anyagi károkra (damnum emergens és lucrum cessans), valamint a nem vagyoni sérelmekre is.

A szerződés megszüntetése, mint jogkövetkezmény ugyancsak felvet egyes jogelméleti kérdéseket. A rendelkezés megszövegezéséből nem következik egyértelműen, hogy a szerződés ex lege érvénytelen, vagy ehhez valamelyik fél kezdeményezése szükséges. ${ }^{44} \mathrm{~A}$ szerződéstől való elállás ex tunc hatállyal teljes egészében szünteti meg a szerződést.

40 Grochowski: i.m., 61., Sieradzka, i.m., Nb 10.

41 Grochowski: i.m., 61., Sieradzka, i.m., Nb 10.

42 Wiewiórowska-Domagalska, Kunkiel-Kryńska: i.m., Nb 52-53.

43 Wiewiórowska-Domagalska, Kunkiel-Kryńska: i.m., Nb 52.

44 Grochowski: i.m., 62. 
Hasonlóképpen, a szankció, amely lehetővé teszi a megfelelő pénzösszeg különféle célokra történő teljesítését, kétértelmű természete miatt ellentmondásokhoz vezethet. ${ }^{45} \mathrm{~A}$ kritikusok azon az állásponton vannak, hogy a rendelkezés egyrészt túlzottan általános megfogalmazást tartalmaz, másrészt, a fogyasztóknak nem áll érdekekében e jogkövetkezmény érvényesítése - bár utóbbi álláspont vitatható. ${ }^{46}$ Ezenkívül vitatható az is, hogy az erre irányuló kérelemnek a vállalkozás felróható magatartásán alapuló tisztességtelen kereskedelmi gyakorlatra kell-e hivatkoznia. ${ }^{47}$ Noha a közérdekü célok, amelyekre összegeket lehet fordítani, meglehetősen szűkre szabottak, a fogyasztónak megengedett, hogy ezzel kapcsolatos álláspontjaikat részletesebben előadják a kérelemben.

Az egyik, a lengyel jogirodalomban kifejtett vélemény ${ }^{48}$ szerint a kisebb súlyú ügyeknek is helyt adó, túlzottan liberális hatósági és bírósági szemlélet a tisztességtelen kereskedelmi gyakorlatról szóló törvény rendelkezéseinek visszaélésszerű használatához vezethet, végső soron a vállalkozások hátrányára. A gyakorlatban azonban a fogyasztók nem sok esetben fordulnak bírósághoz vagy hatósághoz tisztességtelen kereskedelmi gyakorlat miatt, ami azt jelenti, hogy a jogszabály rendelkezéseinek érvényesítése föként közvetlenül a közigazgatási gyakorlat útján valósul meg.

\section{A fogyasztói érdekvédelmet ellátó szervezetek fellépésének lehetőségei}

A fogyasztói érdekképviseleti szervezetek számára is biztosított a lehetőség, hogy hatósághoz (az UOKiK elnökéhez), valamint keresettel bírósághoz forduljanak tisztességtelen kereskedelmi gyakorlat miatt. A hatóság felé tett bejelentésre ugyanazok a - a korábbiakban kifejtett -szabályok vonatkoznak, mint a fogyasztói bejelentések esetén.

Ami a tisztességtelen kereskedelmi gyakorlattal szembeni bírósághoz fordulást illeti, az UCPA 12. $\$(2)$ bekezdése lehetővé teszi ezt az emberi jogi biztos, a pénzügyi ombudsman, fogyaztói érdekek védelmét célul kitűző országos vagy regionális szervezetek, továbbá területi vagy települési önkormányzati fogyasztóvédelmi ombudsmanok számára. Eszemélyek azonban-a fogyasztókhoz

45 J. Szwaja, A. Tischner: Implementacja dyrektywy 2005/29/WE o zwalczaniu nieuczciwych praktyk rynkowych do prawa polskiego. MoP, 2007/20, 1121.; Sieradzka, i.m., Nb 10.

46 Wiewiórowska-Domagalska, Kunkiel-Kryńska: i.m., Nb 58.

47 Lásd erről: Wiewiórowska-Domagalska, Kunkiel-Kryńska: i.m., Nb 59.

48 A. Michalak: Przeciwdziatanie nieuczciwym praktykom rynkowym. Komentarz, C. H. Beck, Warszawa, 2008, Comments to Art. 12, Nb 5. 
képest - csak korlátozottan kezdeményezhetnek eljárás, csupán az alábbi jogkövetkezményeket kérve:

a) a jogsértés megszüntetését, illetőleg abbahagyását;

b) nyilatkozat megtételét (egy vagy több alkalommal), megfelelő tartalommal és megfelelő formában;

c) meghatározott összeg társadalmi célokra történő teljesítését, amely a lengyel kultúra támogatására, a nemzeti örökség vagy a fogyasztók védelmére irányul.

\section{A tisztességtelen kereskedelmi gyakorlat esetén kiszabható jogkövetkezmények típusai és meghatározásuk szempontjai}

Mint ahogyan korábban már említésre került, az UOKIK elnöke bírságot szabhat ki a fogyasztók kollektív érdekeit sértő gyakorlatok tilalmának megsértése miatt. A bírság kiszabása nem kötelező. A jogelmélet számos olyan szempontot meghatározott, amelyet az UOKIK elnökének figyelembe kell vennie a bírság kiszabásáról szóló határozatának meghozatalakor, különösen: ${ }^{49}$ (1) a közérdek veszélyeztetésének mértéke, (2) a jogsértés szándékos volta, (3) a jogsértés időtartama (4) a jogsértésből származó haszon nagysága és (5) a jogsértés először történt-e. Walczak ${ }^{50}$ véleménye szerint UOKiK elnökének az eljárást befejező határozatban részletesen elő kellene adnia a bírság alkalmazására (vagy nem alkalmazására) irányuló döntésének indokait. Rámutat továbbá, hogy a határozatok általában nagyon szűkszavúan magyarázzák indokaikat, lényegében csak arra utalva, hogy a vállalkozással szemben bírság alkalmazása ,indokolt” volt.

Korántsem állítható teljes bizonyossággal, hogy a fenti a szempontok előzetesen ismertek a vállalkozások előtt. Ennek ellenére, ha egy kereskedő az UOKiK elnökének eljárás alá kerül, a kritériumokat már nem nehéz meghatározni.

Mindemellett 2018. december 15-től kezdődően,, a vállalkozások vezető tisztségviselöivel (vagy a vezető testület tagjaival) szemben 2000000 PLN-ig 52 (körülbelül 465000 EUR összegig terjedő),

49 Walczak: i.m., 306.

50 Walczak: i.m., 306-307.

51 A pénzügyi piacok felügyeletének megerősítésével és a befektetők védelmével kapcsolatos egyes jogi aktusok módosításáról szóló 2018. November 9-i törvény (Ustawa z dnia 9 listopada 2018 r. o zmianie niektórych ustaw $w$ celu wprowadzenia uproszczeń dla przedsiębiorców w prawie podatkowym i gospodarczym) Hivatalos Lap, 2018/ 2243. sz.

52 Lengyel złoty. 
pénzügyi ágazatban működő vállalkozások vezető tisztségviselőivel szemben 5000000 PLN-ig terjedő összegü pénzbírságot alkalmazhat. Bírság szabható ki akkor, ha a vezető a jogsértés megállapításának időszakában a feladatkörébe tartozó ügykörben szándékos cselekményével vagy mulasztásával lehetővé tette a vállalkozás számára, hogy megsértse a fogyasztók kollektív érdekeit. A gazdasági versenyről és a fogyasztók védelméről szóló törvény 106b. \$ (3) bekezdése értelmében a kollektív fogyasztói érdekeket sértő magatartás megállapítása esetén a hatóság döntésében bírságot szab ki a vállalkozással szemben.

A gazdasági versenyről és a fogyasztók védelemről szóló törvény 106. \$ (1)-(4) bekezdésének értelmében az UOKiK elnöke a bírság megállapítását megelőző üzleti év forgalmának legfeljebb 10 százalékáig terjedő mértékü bírságot alkalmazhat a vállalkozással szemben, ha - függetlenül szándékosságától megsértette a fogyasztók kollektív érdekeit sértő kereskedelmi gyakorlat tilalmát. Noha a törvény lefekteti a bírság összegével kapcsolatos szabályokat, azt azonban nem határozza meg, hogy mi alapján kell a bírság összegét egyes esetekben meghatározni. ${ }^{53}$ Walczak szerint az UOKiK elnökének a gazdasági versenyről és fogyasztóvédelemről szóló törvény 106. $\$$ (1) (4) bekezdése alapján bírságot kiszabó határozatainak elemzése egy egységes sémára enged következtetni. ${ }^{54}$ Eszerint először az elnök meghatározza a bírság lehetséges maximális összegét, amely a vállalkozás bírság megállapítását megelőző üzleti évi forgalmától függ. Ezután a gazdasági versenyről és fogyasztóvédelemről szóló törvény 111 \ (1) bekezdése alapján az elnök meghatározza a bírság alapösszegét, majd a 111. \$ (3) és (4) bekezdése alapján az elnök mérlegeli az esetre alkalmazható enyhítő vagy súlyosító körülményeket. Végül e mérlegelés alapján megállapított összeg képezi a kiszabott bírság összegét.

Az UOKiK elnökének bírságot kiszabó határozata bírósági felülvizsgálat tárgya lehet. A Hivatal által a 2013 - 2015 évekre vonatkozóan szolgáltatott adatai azt mutatják, hogy a bírósági felülvizsgálat eredményeként a bírságok összegét 75 522520 PLN-ről 30824974 PLN-ra csökkentették az eljáró bíróságok. 2017ben a fogyasztók kollektív érdekeinek megsértéséért kiszabott bírságok teljes összege 78,8 millió PLN (a legmagasabb kiszabott bírság 25,8 millió PLN volt), ${ }^{55}$ 2018-ban pedig 16,9 millió PLN volt. ${ }^{56}$

53 Walczak: i.m., 307.

54 Walczak: i.m., 307.

55 https://www.uokik.gov.pl/aktualnosci.php?news_id=14857 (letöltés dátuma: 2020.03.10.)

56 https://www.uokik.gov.pl/aktualnosci.php?news_id=16026 (letöltés dátuma: 2020.03.10.) 


\section{Az átlagfogyasztó megítélése és a fogyasztói döntéseket befolyásoló tényezők a hatósági és bírósági eljárások során}

A tisztességtelen kereskedelmi gyakorlatról szóló törvény 3. \$ (8) bekezdése az átlagfogyasztót észszerűen jól informált, figyelmes és körültekintő fogyasztóként határozza meg. Ennek megítélése során figyelembe kell venni a társadalmi, kulturális és nyelvi tényezőket, valamint azt, hogy a fogyasztó olyan azonosítható fogyasztói csoportba tartozik-e, amely különösen érzékeny a kereskedelmi gyakorlatra, vagy az alapul szolgáló termékre, amelyre a kereskedelmi gyakorlat vonatkozik, különös tekintettel az egyéni tulajdonságokra, például életkorra, testi vagy szellemi fogyatékosságra vagy hiszékenységre.

$\mathrm{Az}$ átlagfogyasztó fogalmát egy olyan meghatározott, egyértelműen azonosítható fogyasztói csoport összefüggésében kell értékelni, amelyre a kereskedelmi gyakorlat irányul. A jogirodalom ${ }^{57}$ és az ítélkezési gyakorlat által ismert dilemma az átlagfogyasztó európai uniós és a nemzeti modell közötti különbség. Ez tükröződik a Bizottság 2016. évi iránymutatásában is, ${ }^{58}$ amelyben a Bizottság rámutat, hogy a 2005/29/EK irányelvben megfogalmazott teljes harmonizáció elvétől függetlenül, elméletileg lehetséges az átlagfogyasztói teszt alapján megkövetelni, hogy a külföldi vállalkozás kiegészítő információkat szolgáltasson a fogyasztónak a társadalmi, kulturális vagy nyelvi tényezőkről (lásd az Európai Unió Bíróságának C-220/98. sz. Estée Lauder Cosmetics ügyben hozott ítéletét). ${ }^{59}$

E tekintetben a Varsói Fellebbviteli Bíróság 2013. január 17-i ítéletében ${ }^{60}$ kimondta, hogy míg a tisztességtelen kereskedelmi gyakorlatokról szóló törvény 1 . $\$(8)$ bekezdése az átlagfogyasztót észszerüen tájékozott, figyelmes és körültekintőként határozza meg, addig a magatartása értékelése során figyelembe kell venni a társadalmi, kulturális és nyelvi tényezőket. Közismert, hogy egy átlagos lengyel személy, beleértve az átlagfogyasztót is, társadalmi és kulturális okok miatt a jogban kevésbé jártas, amely tény különösen jól ismert a jogaikban tájékozottabb körökben is. Ezért Lengyelországban a kellően tájékozott, figyelmes és körültekintő fogyasztó szintje, azaz az átlagfogyasztó, semmilyen módon sem

57 M. Sieradzka: Wzorzec "przeciętnego konsumenta" w dyrektywie 2005/29/WE o nieuczciwych praktykach handlowych i jego implikacje dla prawa polskiego. EPS, 6/2008. 22.

58 Commission Staff Working Document Guidance on the implementation/application of Directive 2005/29/ EC on Unfair Commercial Practices, SWD/2016/0163 Final, 51.

59 C-220/98. sz. Estée Lauder Cosmetics ügyben 2000. január 13-án hozott ítélet (ECLI:EU:C:2000:8)

60 Varsói Fellebbviteli Bíróság 2013. január 17-i ítélete (VI Aca 1069/12). 
kapcsolódhat a nyugat-európai átlagfogyasztó szintjéhez. Bár megjegyzendő, hogy évtizedek óta zajlanak erőfeszítések annak érdekében, hogy olyan intézkedéseket vezessenek be, amelyek növelik a fogyasztói tudatosság szintjét.

Az átlagfogyasztó tesztjét a bírói gyakorlat fejlesztette tovább. A Legfelsőbb Bíróság a 2005. április 23-i ítéletében, ${ }^{61}$ amely a 2005/29/EK irányelv (18) preambulum bekezdésére utal, hangsúlyozta, hogy az átlagfogyasztói teszt nem statikus, és az átlagfogyasztó tipikus magatartásának a konkrét esetben történő megállapítása során a nemzeti bíróságoknak és a közigazgatási szerveknek figyelembe véve az Európai Bíróság esetjogát - a saját meggyőződésükre kell támaszkodniuk

A lengyel ítélkezési gyakorlat viszonylag gyakran utal arra, hogy egy átlagfogyasztó hogyan érzékeli a reklámot. Elvárható például, hogy egy átlagfogyasztó megértse a reklámhirdetések bizonyos hétköznapi állításait, beleértve a túlzások használatának felismerését is. Ez nem azt jelenti, hogy egy reklám felhasználhat minden lehetséges „trükköt”, így például a hamis információkat vagy a fogyasztókat félrevezető információkat. ${ }^{62}$ A Legfelsőbb Bíróság szerint ${ }^{63}$ az átlagfogyasztónak van bizonyos fokú ismerete annak a gazdasági valóságnak a vonatkozásában, amelyben a reklám őket, mint fogyasztókat célozza. Azáltalában elvárható figyelem és körültekintés tanúsításával az átlagfogyasztó bizonyos fokú észszerü kritikával használja fel ezen ismereteit a reklám elemzésére. Az átlagfogyasztóra jellemző, hogy tudatában van annak a ténynek, hogy a reklámban közvetített üzenet nem mindig felel meg teljesen a valóságnak, továbbá hogy túlzásokat alkalmaz, ez azonban semmiképpen sem igazolja a tudatosan hamis információk szolgáltatását.

A Varsói Fellebbviteli Bíróság a 2017. március 22-i ítéletben ${ }^{64}$ egy vizsgálati módszert irányzott elő az átlagfogyasztó megállapítására, megtévesztő reklám esetén. A bíróság két vizsgálati szempontot állapít meg: a reklámozott termék vagy szolgáltatás típusát (amely lehetővé teszi a hirdetés címzettjének azonosítását) és a reklám megjelenésének formáját (sajtó, televízió, hirdetőtábla stb.). Az első kritérium alapvető jelentéssel bír annak szempontjából, hogy rekonstruálják az átlagfogyasztó rendelkezésére álló információinak körét. A második kritérium az információk körének pontosabb meghatározását

61 Legfelsőbb Bíróság 2005. április 23-i ítélete (III CSK 377/07).

62 Versenyügyi és Fogyasztóvédelmi Bíróság 2013. augusztus 29-i ítélete (XVII AmA 127/11).

63 Legfelsőbb Bíróság 2014. március 4-i ítélete (III SK 34/13).

64 Varsói Fellebbviteli Bíróság 2017. március 22-i ítélete (VI Aca 1863/15). 


\section{TiSZTESSÉGTELEN KERESKEDELMI GYAKORLATOK - LENGYELORSZÁG}

szolgálja, a reklám terjesztésének módjától függően. Ez a két szempont jelölheti ki azoknak a fogyasztóknak a körét, akiket a tényállás megállapítása során a reklám feltételezett átlagos címzettjeinek lehet tekinteni.

A Legfelsőbb Bíróság álláspontja szerint ${ }^{65}$ a biztosítás és a pénzügyi szolgáltatások területén nem vélelmezhető az átlagfogyasztó hozzájárulása a biztosítási szerződés megkötéséhez, amennyiben nem biztosítottak lehetőséget neki arra, hogy elözetesen megismerje a szerződési feltételeket (még akkor sem, ha a fogyasztó valójában nem olvassa el azokat). Az átlagfogyasztónak a tisztességtelen kereskedelmi gyakorlatokról szóló törvény által bevezetett modellje feltételezi, hogy a fogyasztó azután hozza meg a szerződéssel kapcsolatos döntéseket, miután felvilágosítást kapott, és kellően megértette a vállalkozás azon közléseit, amelyek célja a fogyasztó szerződéskötésre való rábírása.

Azon piaci gyakorlatok esetén, amelyek nem a marketing tevékenységgel kapcsolatosak, az átlagfogyasztói modell alapján az a vélelem áll fenn, hogy a fogyasztó megismeri és megérti azokat a konkrét feltételeket, amelyek a vállalkozás szerződéskötési ajánlatában szerepelnek. Ezek alapvetően azok az elemek, amelyek megkülönböztetik a vállalkozás ajánlatát a piaci kínálattól. A bankok által nyújtott szolgáltatásokkal kapcsolatban a fogyasztó nem számít tudatlan személynek, akit minden esetben védelemben kell részesíteni a szakemberekkel folytatott interakciói során. Az átlagfogyasztó tájékozott, körültekintő és észszerüen viselkedik. A Legfelsőbb Bíróság szerint ${ }^{66}$ még azoknak a fogyasztóknak is, akiknek nincsenek szakirányú ismereteik a banki termékekkel kapcsolatban, meg kell érteniük, hogy egy bank által kínált szolgáltatással összefüggő, bankszámla nyitásáról szóló szerződés megkötése nem lehetséges, amennyiben a fogyasztó nem fizet be egy bizonyos összeget, valamint nem kap tájékoztatást a bankszámlaszámról.

A lengyel ítélkezési gyakorlatban törekvés mutatkozik arra, hogy növeljék az átlagfogyasztókkal szembeni elvárások szintjét. ${ }^{67}$ Például a 2008. április 23-i ítéletben ${ }^{68}$ a Legfelsőbb Bíróság hangsúlyozta, hogy az Európai Bíróság ítélkezési gyakorlatának és az EU hatására, a lengyel ítélkezési gyakorlat és a jogirodalom óvatosan ugye, de a hiányos memóriájú átlagfogyasztóval szemben a figyelmes, körültekintő és kellően tájékozott átlagfogyasztót veszi figyelembe.

65 Legfelsőbb Bíróság 2014. május 15-i ítélete (III SK 75/13)

66 Legfelsőbb Bíróság 2013. november 29-i ítélete (I CSK 87/13)

67 Wiewiórowska-Domagalska, Kunkiel-Kryńska: i.m., Nb 84-111.

68 Legfelsőbb Bíróság 2008. április 23-i ítélete (III CSK 377/07) 
A modellt alkalmazása az adott eset körülményei szerint módosulhat, ugyanis a fogyasztók megtévesztésének veszélye megállapításakor azt az átlagfogyasztót fontos figyelembe venni, akire a (tisztességtelen) gyakorlat irányult, vagy akit a gyakorlat elért. Úgy tűnik, a Legfelsőbb Bíróságnak nem az az álláspontja, hogy a fogyasztónak „észszerüen”, „amennyire csak lehetséges”, „kello”en” („rozsądnie”, „w miarę”, „dosyć”) tájékozottnak, és ,észszerűen”, „amennyire csak lehetséges”, „kello”en” („rozsądnie”, „w miarę”, „dosyć”) figyelmesnek és körültekintőnek kell lennie.

Hasonlóképpen, a Varsói Fellebbviteli Bíróság a 2007. december 6-i ítéletében ${ }^{69}$ úgy határozott, hogy a „fapados légitársaságok” hirdetésének címzettjeit jól tájékozott, kellő információval, valamint a hasonló működésű vállalkozásokkal kapcsolatos élettapasztalattal rendelkező személyeknek kell tekinteni, amely értékelés kiterjed az online jegyvásárlással kapcsolatos magatartásukra is, és ezáltal megkülönbözteti őket az átlagfogyasztók körétől.

A Legfelsőbb Bíróság 2014. május 8-i ítéletében ${ }^{70}$ úgy határozott, hogy a vállalkozás gyakorlata olyan barkácsáruházi ügyfelekre irányult, akik nem tartoznak abba a típusú fogyasztói kategóriába, akiket társadalmi, kulturális vagy nyelvi okok miatt különösen veszélyeztetne a gyakorlat. Ezért a barkácsáruházak vásárlóját panaszjogának érvényesítése esetén az általános szabályok szerint kell figyelembe venni. ${ }^{71}$ Ezzel összefüggésben, a Legfelsőbb Bíróság úgy vélte, hogy a barkácsáruházakban értékesített termékek tulajdonságai - még akkor is, ha azokat reklám hatására vásárolják meg - igazolják azt a feltételezést, miszerint a termék vásárlói - tekintettel az áruk jellegére és céljára - kellő figyelmet fordítanak a vásárolni kívánt termékre. Ezenkívül a barkácsáruházakban vásárolt termékek nem a mindennapos használat körébe tartozó termékek, amelyeket mérlegelés nélkül szoktak vásárolni. Sőt, ha a vásárolt termékek hibásak, és a fogyasztó visszatér a boltba azzal a céllal, hogy az áru hibája miatt szavatossági igényt érvényesítsen, akkor sem lehet azt vélelmezni, hogy a fogyasztó nem volt kellően tájékozott, figyelmes és körültekintő.

Hasonló vélelem vonatkozik a fogyasztó szavatossággal (hibás teljesítéssel) összefüggő jogaival kapcsolatos ismeretei tekintetében is. A Legfelsőbb Bíróság úgy ítélte meg, hogy bár a fogyasztó megtéveszthető a vállalkozás által azon tekintetben, hogy milyen jogai vannak hibás

69 Varsói Fellebbviteli Bíróság 2007. december 6-i ítélete (VI Aca 842/07)

70 Legfelsőbb Bíróság 2014. május 8-i ítélete (III SK 45/13)

71 A tisztességtelen kereskedelmi gyakorlatokról szóló törvény 2. \$8. pontja. 


\section{TisZTESSÉGTELEN KERESKEDELMI GYAKORLATOK - LENGYELORSZÁG}

teljesítésesetén (például az üzlet által készített formanyomtatvány hiányos, pontatlan tájékoztatást tartalmaz a fogyasztók jogairól, továbbá olyan fogyasztói kötelezettségvállalást tartalmaz, hogy további eljárást nem fog indítani), azonban egy ilyen kikötés esetén az átlagfogyasztóval szemben nem azt kell vélelmezni, hogy 2. cikk (8) bekezdése szerinti jogainak kizárását nem értette meg, hanem épp a döntés megalapozottságát, azaz hogy annak aláirásával a további eljárás kezdeményezésének jogáról kifejezetten lemondott. 


\section{Forrásjegyzék}

1. M. Grochowski: Wadliwość umów konsumenckich (w świetle przepisów o nieuczciwych praktykach rynkowych). Państwo i Prawo, 2009/7. 59-71.

2. A. Jurkowska-GomuŁka: Objaśnienia do art. 100. \$. In: T. Skoczny (ed.): Ustawa o ochronie konkurencji i konsumentów. Komentarz. C. H. Beck, Warszawa, 2014, 1195-1207.

3. K. Конuтек: Rekompensata publiczna - Kontrowersyjny środek stosowany przez prezesa UOKiK. 2018. 03. 08., elérhető: http://kohutek.pl/ rekompensata-publiczna-kontrowersyjny-srodek-stosowany-prezesa-uokik/ (letöltés dátuma: 2020.03.10.)

4. A. Michalak: Przeciwdziałanie nieuczciwym praktykom rynkowym. Komentarz, C. H. Beck, Warszawa, 2008.

5. K. Róziewicz-Ładoń: Postępowanie przed Prezesem Urzędu Ochrony Konkurencji $i$ Konsumentów $w$ sprawach praktyk ograniczających konkurencje. Wolters Kluwer, Warszawa, 2011.

6. M. SieradzKa (ed.): Ustawa o przeciwdziataniu nieuczciwym praktykom rynkowym. Komentarz. Wolters Kluwer, Warszawa, 2008.

7. M. SieradzKa: Wzorzec "przeciętnego konsumenta" w dyrektywie 2005/29/ WE o nieuczciwych praktykach handlowych i jego implikacje dla prawa polskiego. EPS, 6/2008. 19-23.

8. M. Strzelecki: Nieuczciwe praktyki handlowe a ustawa o zwalczaniu nieuczciwej konkurencji. Ikar, Vol. 5, 2016/3, 51-67.

9. M. STRZELECKi: Praktyki naruszające zbiorowe interesy konsumentów w świetle zupetnej harmonizacji praktyk handlowowych wynikajacej $z$ dyrektywy 2005/29/E o nieuczciwych praktykach handlowych. Krajowa Konferencja Konsumencka, 2016.

10. D. Sylwestrzak: Postęowanie przed Prezesem Urzędu Ochrony Konkurencji i Konsumentów. LexisNexis, Warszawa, 2012.

11. J. Szwaja, A. Tischner: Implementacja dyrektywy 2005/29/WE o zwalczaniu nieuczciwych praktyk rynkowych do prawa polskiego. MoP, 2007/ 20. 1121.

12. A. Tischner: Miejsce implementacji dyrektywy 2005/29/WE do prawa polskiego. In: E. Nowińska, D. Kasprzycki: Nieuczciwe praktyki rynkowe. Ocena regulacji, Kraków, 2012, 53-63. 


\section{TisZTESSÉGTELEN KERESKEDELMI GYAKORLATOK - LENGYELORSZÁG}

13. T. Walczak: Postępowanie w sprawach z zakresu ochrony zbiorowych interesów konsumentów jako szczególny rodzaj postępowania administracyjnego. (Rozprawa doktorska), Poznań, 2018.

14. A. Wiewiórowska-Domagalska, A. Kunkiel-Kryńska: Prawo konsumenckie: komentarz. Comments to Art. 1-12. In: K. Osajda (ed.): Tom VII. Komentarze Prawa Prywatnego. C. H. Beck, Warszawa, 2019.

15. Az Európai Parlament és a Tanács 2005/29/EK irányelve (2005. május 11.) a belső piacon az üzleti vállalkozások fogyasztókkal szemben folytatott tisztességtelen kereskedelmi gyakorlatairól, valamint a 84/450/EGK tanácsi irányelv, a 97/7/EK, a 98/27/EK és a 2002/65/EK európai parlamenti és tanácsi irányelvek, valamint a 2006/2004/EK európai parlamenti és tanácsi rendelet módosításáról, HL L 149, 2005.6.11. 22-39.

16. 1964. április 23-i törvény a polgári törvénykönyvről (Ustawa z dnia 23 kwietnia 1964 r. Kodeks cywilny)

17. 1993. április 16-i törvény a tisztességtelen verseny tilalmáról (Ustawa $z$ dnia 16 kwietnia 1993 r. o zwalczaniu nieuczciwej konkurencji)

18. 2007. február 16-i törvény a gazdasági versenyről és a fogyasztók védelméről (Ustawa z dnia 16 lutego 2007 r. o ochronie konkurencji i konsumentów)

19. 2007. augusztus 23-i törvény a tisztességtelen kereskedelmi gyakorlat tilalmáról (Ustawa $z$ dnia 23 sierpnia 2007 r. o przeciwdziataniu nieuczciwym praktykom rynkowym)

20. 2018. november 9-i törvény a pénzügyi piacok felügyeletének megerősítésével és a befektetők védelmével kapcsolatos egyes jogi aktusok módosításáról (Ustawa z dnia 9 listopada 2018 r. o zmianie niektórych ustaw w celu wprowadzenia uproszczeń dla przedsiębiorców w prawie podatkowym i gospodarczym) Hivatalos Lap, 2018/2243. sz.

21. Európai Unió Bírósága C-220/98. sz. Estée Lauder Cosmetics ügyben 2000. január 13-án hozott ítélete (ECLI:EU:C:2000:8)

22. Legfelsőbb Bíróság a 2005. április 23-i ítélete (III CSK 377/07)

23. Legfelsőbb Bíróság 2014. május 8-i ítélete (III SK 45/13)

24. Legfelsőbb Bíróság 2014. május 15-i határozata (III SK 75/13)

25. Legfelsőbb Bíróság 2016. június 2-i ítélete (I CSK 119/16)

26. Katowicei Fellebbviteli Bíróság ítélete (V Aca 562/15)

27. Varsói Fellebbviteli Bíróság 2007. december 6-i ítélete (VI Aca 842/07) 
28. WSA (Vajdaság Közigazgatási Bíróság) 2008. július 8-i határozata (VII SA / Wa 535/08, CBOSA)

29. Varsói Fellebbviteli Bíróság 2008. július 10-i ítélete (VI Aca 306/08)

30. Varsói Fellebbviteli Bíróság 2013. január 17-i ítélete (VI Aca 1069/12).

31. Versenyügyi és Fogyasztóvédelmi Bíróság 2013. augusztus 29-i ítélete (XVII AmA 127/11)

32. https://radareklamy.pl/kodeks-etyki/ (letöltés dátuma: 2020.03.10.)

33. https://zpf.plletyka/zasady-dobrych-praktyk/ (letöltés dátuma: 2020.03.10.)

34. https://www.uokik.gov.pl/faq_zagadnienia_ogolne.php\#faq1198

35. https://www.uokik.gov.pllaktualnosci.php?news_id=14857 (letöltés dátuma: 2020.03.10.)

36. https://www.uokik.gov.pllaktualnosci.php?news_id=16026 (letöltés dátuma: 2020.03.10.)

37. https://odpowiedzialnasprzedaz.pl/wp-content/uploads/2020/01/ Regulamin_6-11.pdf(letöltés dátuma: 2020.03.12.) 
Dr. Aneta Wiewiórowska-Domagalska PhD, 2015. januárjától az Osnabrücki Egyetem Európai Jogi Intézetének vezető kutatója. 2019-ben a lengyel ombudsman által létrehozott Fogyasztóvédelmi Szakértői Csoport társelnökévé nevezték ki. Jogi diplomáját a Varsói Egyetemen, PhD fokozatát az Utrechti Egyetemen szerezte. Kutatóként vett részt az európai polgári törvénykönyv munkacsoport munkájában (a Principles of European Law on Sales - az Európai Adásvételi Jog Alapelvei című munka társszerzője). 2008-2014 között a lengyel igazságügyi minisztérium vezető tanácsadójaként dolgozott, ahol részt vett a magánjogi területre vonatkozó jogalkotási javaslatok előkészítésében és végrehajtásában, valamint az Európai Tanács magánjogi jogintézményeket érintő tárgyalásain. Wiewiórowska-Domagalska a lengyel soros elnökség idején a Közös Európai Adásvételi Jog (Common European Sales Law - CESL) munkacsoportjának elnöke volt. 2007 és 2015 között a lengyel polgári jogi kodifikációs bizottság különféle munkacsoportjainak tagja volt. Szakértőként vesz részt az Európai Jogi Intézet (European Law Institute - ELI) Online Közvetítő Szolgáltatások Modell-szabályai címü projektben, és az ELI Végrehajtóanácsának tagja. 
